(2) OPEN ACCESS

${ }^{1}$ Endocrinology, Walter Reed National Military Medical Center, Bethesda, Maryland, USA

${ }^{2}$ Medicine, Uniformed Services University of the Health Sciences, F. Edward Hebert School of Medicine, Bethesda, Maryland, USA

${ }^{3}$ Pathology, Walter Reed National Military Medical Center, Bethesda, Maryland, USA

\section{Correspondence to Dr Thanh Duc Hoang; tdhdthanh@gmail.com}

Accepted 11 November 2021

Check for updates

(C) BMJ Publishing Group Limited 2021. Re-use permitted under CC BY-NC. No commercial re-use. See rights and permissions. Published by BMJ.

To cite: Bloomer ZW,

Knee TS, Rubin ZS, et al. BMJ Case Rep 2021;14:e246776. doi:10.1136/bcr-2021-

246776

\title{
Case of an atypical pituitary abscess
}

\author{
Zachary W Bloomer, ${ }^{1,2}$ Treyce S Knee, ${ }^{1,2}$ Zachary S Rubin, ${ }^{3}$ Thanh Duc Hoang $\mathbb{C}^{1,2}$
}

\section{SUMMARY}

A pituitary abscess is a rare intrasellar infection. Correct identification can be challenging preoperatively given its non-specific symptoms and imaging findings. We report a case of a young woman presenting with secondary amenorrhea, visual field deficits and a $2.6 \mathrm{~cm}$ pituitary lesion diagnosed to be a craniopharyngioma. A concomitant unexpected pituitary abscess was diagnosed intraoperatively without associated meningeal symptoms.

\section{BACKGROUND}

Pituitary abscess is an uncommon lesion in the pituitary, accounting for $<1 \%$ of all pituitary lesions. In most cases, it is uncertain what the exact pathogen is, with treatment entailing both surgical and antibiotic therapies. Although clinical symptoms are non-specific compared with other pituitary lesions, pituitary abscess can be life-threatening. However, presurgical diagnosis is challenging due to the non-specific nature of presenting symptoms, non-specific imaging findings, and the rarity of the disease. We report a patient with a pituitary abscess that was discovered during surgery for a known enlarging pituitary lesion that caused visual deficits and headaches.

\section{CASE PRESENTATION}

A 36-year-old caucasian woman presented to the endocrinology clinic for a preoperative evaluation of an enlarging pituitary lesion. She had a

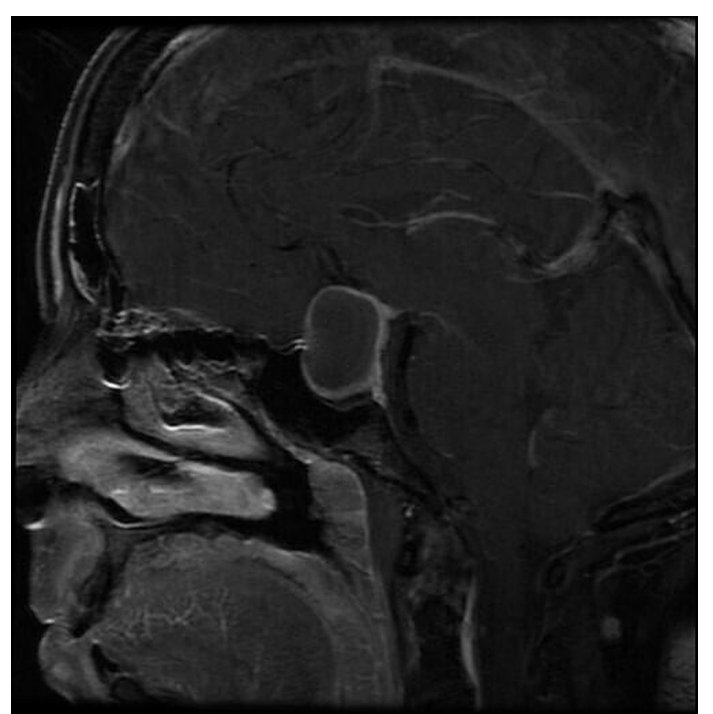

Figure 1 Preoperative pituitary MRI shows a rimenhancing $2.6 \mathrm{~cm}$ lesion with a new signal intensity in the cystic cavity suggestive of haemorrhage and compression of the optic chiasm, which had enlarged from $1.9 \mathrm{~cm}$ on prior imaging.

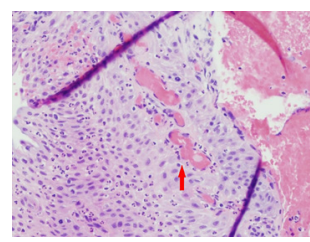

Figure 2 Histopathology of the lesion shows the squamous cells with marked acute inflammation. In the centre (red arrow), there are blood-filled fibrovascular cores, indicating papillae.

medical history of ankylosing spondylitis previously managed on immune modulating therapy but had stopped 1 year prior to presentation. Two years prior, she was diagnosed with a pituitary macroadenoma during an evaluation of secondary amenorrhea. Biochemical evaluation was negative for hypersecretion but did reveal secondary hypothyroidism: thyrotropin (TSH) $0.789 \mathrm{uIU} / \mathrm{mL}$ (normal $0.27-4.2$ ), free thyroxine (FT4) $0.75 \mathrm{ng} / \mathrm{dL}$ (normal 0.93-1.7), follicle stimulating hormone (FSH) 2.9 $\mathrm{mIU} / \mathrm{mL}$ (normal follicular phase 3.5-12.5, ovulation phase 4.7-21.5), luteinising hormone (LH) $2.44 \mathrm{mIU} / \mathrm{mL}$ (normal follicular phase 2.4-12.6, ovulation phase 14.0-95.6), estradiol $<5.0 \mathrm{pg} / \mathrm{mL}$ (normal follicular phase 12.4-233, ovulation phase 41.0-398). Visual field exam at that time was unremarkable. A pituitary MRI showed a $1.9 \mathrm{~cm}$ lesion with cystic features, suggestive of a cystic adenoma. The patient was subsequently lost to follow-up until she presented again complaining of worsening vision, headaches and weight loss. She had been in her usual state of health until about 6 months prior to presentation when she developed acute worsening of her chronic headaches followed by unintentional weight loss of 30 pounds over 6 months. The patient denied recent illness or fevers. Repeat pituitary MRI at this time revealed interval growth of the lesion to $2.6 \mathrm{~cm}$ with a new signal intensity in the cystic cavity suggestive of haemorrhage and compression of the optic chiasm (figure 1).

On examination, she was hemodynamically stable and afebrile (blood pressure 116/82 mm $\mathrm{Hg}$, heart rate $74 \mathrm{bpm}$, respiratory rate 16 , oxygen saturation $100 \%$ room air and temperature $97^{\circ} \mathrm{F}$ ). Formal visual field testing revealed bitemporal hemianopsia. Laboratory evaluation was negative for leucocytosis but revealed a low morning serum cortisol of $3.0 \mu \mathrm{g} / \mathrm{dL}$ (normal>10) consistent with preoperative adrenal insufficiency. Insulin-like growth factor 1 (IGF-1) level was low at $61 \mathrm{ng}$ / $\mathrm{mL}$ (normal 79-259), but an FT4 level was normal on levothyroxine for her known secondary hypothyroidism. Surgical excision of the mass revealed unexpected purulent fluid with culture growing Staphylococcus epidermidis. Histology revealed 


\begin{tabular}{|c|c|c|}
\hline Laboratory findings (reference) & Preoperative & Postoperative \\
\hline Prolactin $(4.79-23.3 \mathrm{ng} / \mathrm{mL})$ & $<0.2$ & 13.9 \\
\hline $\begin{array}{l}\text { Estradiol } \\
\text { Follicular phase }(12.4-233 \mathrm{pg} / \mathrm{mL}) \\
\text { Ovulation phase }(41.0-398 \mathrm{pg} / \mathrm{mL}) \\
\text { Luteal phase }(22.3-341 \mathrm{pg} / \mathrm{mL})\end{array}$ & $<5.0$ & $<5.0$ \\
\hline $\begin{array}{l}\text { FSH } \\
\text { Follicular phase }(3.5-12.5 \mathrm{mlU} / \mathrm{mL}) \\
\text { Ovulation phase }(4.7-21.5 \mathrm{mIU} / \mathrm{mL}) \\
\text { Luteal phase }(1.7-7.7 \mathrm{mlU} / \mathrm{mL})\end{array}$ & 4.1 & 3.6 \\
\hline 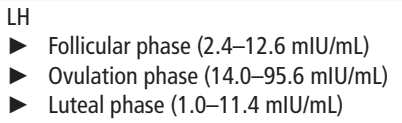 & 1.16 & 2.01 \\
\hline TSH $(0.27-4.2 \mu \mathrm{lU} / \mathrm{mL})$ & 0.055 & 0.070 \\
\hline FT4 (0.93-1.7 ng/dL) & 1.33 & 1.13 \\
\hline Total thyroxine $(4.5-12.0 \mu \mathrm{g} / \mathrm{dL})$ & 6.6 & 5.7 \\
\hline IGF-1 (79-259 ng/mL) & 61 & 85 \\
\hline Serum cortisol (6.2-19.4 $\mu \mathrm{g} / \mathrm{dL})$ & 3.0 & 12.3 \\
\hline Serum ACTH $(7.2-63.3 \mathrm{pg} / \mathrm{mL})$ & 25.3 & 39.2 \\
\hline Serum osmolality (275-295 mOsmol/kg) & 295 & 286 \\
\hline Urine osmolality (50-1400 m0smol/kg) & 512 & 279 \\
\hline
\end{tabular}

ACTH, adrenocorticotropic hormone; $\mathrm{FSH}$, follicle stimulating hormone; $\mathrm{FT} 4$, free thyroxine; IGF-1, insulin-like growth factor 1 ; LH, luteinising hormone; TSH, thyrotropin.

fragments of non-keratinised squamous epithelium with acute inflammation and papillae in the background of haemorrhage, fibrosis and compressed pituitary gland (figure 2). Chromogranin was negative in the squamous epithelium but reactive in the pituitary gland. TTF1 staining is negative, beta-catenin is strongly positive and BRAF V600E is positive. These findings confirmed a craniopharyngioma.

Following surgery, the patient was initiated on broad spectrum antibiotics for 8 weeks. She was initially treated with vancomycin, metronidazole, and ceftriaxone before transitioning to daptomycin and ertapenem as an outpatient. She was placed on physiologic hydrocortisone in addition to maintaining preoperative levothyroxine dose. After 8 weeks of antibiotic therapy, repeat evaluation demonstrated recovery of adrenal axis (peak stimulated serum cortisol $18.1 \mu \mathrm{g} / \mathrm{dL}$, adrenocorticotropic hormone $39.2 \mathrm{pg} / \mathrm{mL}$ (normal 7.2-63.3)) and normalised IGF-1 level.

Three months postoperatively, her visual deficit, weight loss, headaches and adrenal insufficiency resolved, but the previously diagnosed secondary hypogonadism and hypothyroidism persisted. Postoperative laboratory findings showed prolactin $13.9 \mathrm{ng} / \mathrm{mL}$, FSH $3.6 \mathrm{mIU} / \mathrm{mL}, \mathrm{LH} 2.01 \mathrm{mIU} / \mathrm{mL}$ and estradiol $<5.0 \mathrm{pg} / \mathrm{mL}$ (table 1 ). Pituitary MRI (3 months postoperatively) revealed resolution of rim-enhancing lesion/collection within the sellar/suprasellar region without features concerning for infection (figure 3).

\section{DISCUSSION}

This case report presents a woman diagnosed with a pituitary abscess discovered during surgery for a cystic pituitary adenoma with haemorrhagic features. Differential diagnosis of cystic pituitary lesions includes cystic pituitary adenoma, craniopharyngioma, Rathke's cleft cyst. Pituitary abscesses are rare, representing $<1 \%$ of pituitary lesions, with 300 cases reported globally. ${ }^{12}$

Risk factors for developing pituitary abscesses include structural disorders such as pre-existing pituitary lesions such as craniopharyngioma, pituitary adenoma and Rathke's cleft cyst,

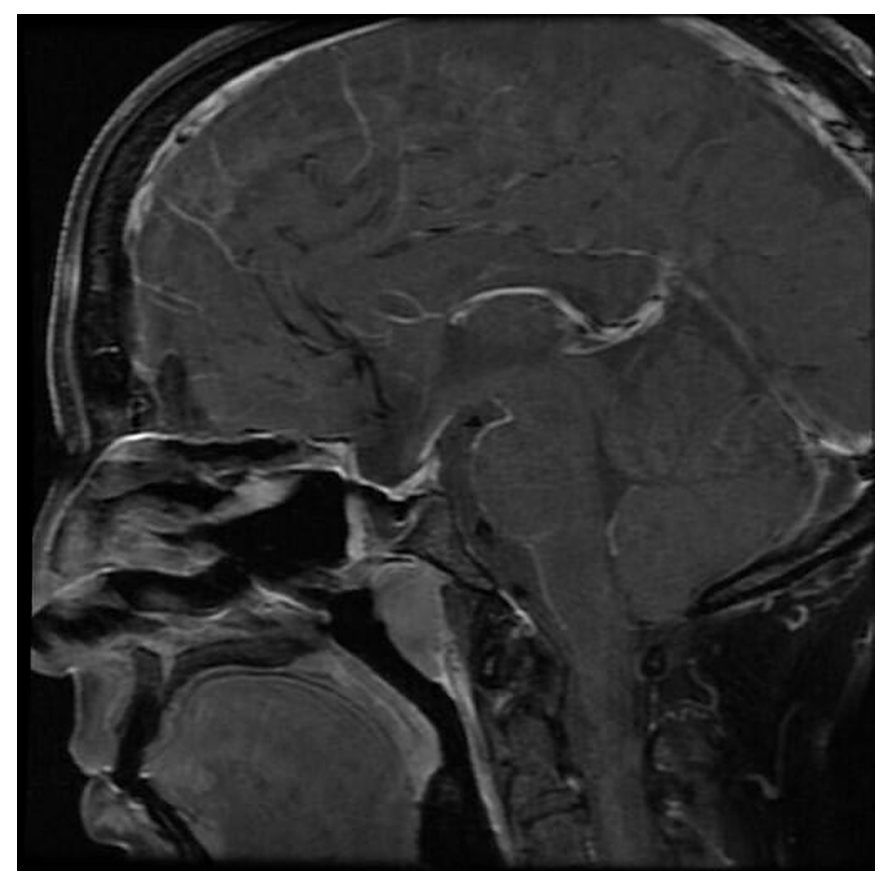

Figure 3 Postoperative pituitary MRI shows resolution of rimenhancing lesion/collection within the selllar/suprasellar region without features concerning for infection.

as well as historical features such as immunosuppression, prior surgical intervention in the sella or irradiation to that area. ${ }^{34}$ The most common risk factor reported was history of pituitary surgery, present in $38.5 \%-41.7 \%$ of cases. However, $70 \%$ of cases occur de novo in a normal pituitary gland. ${ }^{2-8}$ Abscesses can arise either by haematogenous seeding of the pituitary gland or by extension from an adjacent infection, such as meningitis, sphenoid sinusitis, thrombophlebitis or contaminated cerebrospinal fluid (CSF) fistula. ${ }^{467}$ Causative organisms described in causing pituitary abscesses represent a wide spectrum of pathogens. Most common are gram-positive cocci (50\%); other agents are gramnegative bacilli and in immunocompromised individuals, fungi such as yeast, aspergillus and histoplasma have been reported. In up to $60 \%$ of cases, no pathogen could be identified, which can occur if there is preoperative antibiotic therapy or inadequate collection technique. ${ }^{2-8}$ In our case, the patient had a known history of a pituitary lesion, which is a risk factor for developing abscess. In this patient, the culture grew S. epidermidis, although there was concern for potential uncultured organisms.

Preoperative diagnosis can be challenging, both because of the rarity of the disease and the non-specific symptoms. In our patient, an abscess was not suspected given her lack of fever, leucocytosis or meningeal symptoms. However, fever has only been reported in $13 \%-57 \%$ of cases and meningismus symptoms reported in $16 \%-57 \%$. The most common presenting complaint was headache (69\%-100\%), followed by anterior pituitary dysfunction (54\%-84\%) and visual disturbances (27.3\%$100 \%) .^{2-8}$ Unfortunately, these symptoms are non-specific for pituitary abscess and can be seen with pituitary lesions. Diabetes insipidus is reported in $41 \%-70 \%$ of cases, which is a less common endocrinopathy to occur preoperatively. ${ }^{367}$ If there is concern, a patient has developed a pituitary abscess, specific questions regarding polyuria, polydipsia or nocturia may help narrow the differential. There has been consideration to classify abscesses into acute, subacute and chronic categories finding 
infectious symptoms more common in the acute and subacute categories and lacking in the chronic category. ${ }^{367}$

Preoperative imaging is an effective way of characterising pituitary lesions. Computer tomography, though not the preferred imaging modality to characterise pituitary lesions, typically shows erosion and enlargement of the sella turcica and in some cases a well-defined low-attenuation rounded lesion with ring enhancement. The preferred imaging modality is MRI. Typical features include cystic lesions with isointensity or hypointensity on T1-weighted and isointensity or hyperintensity on T2-weighted imaging. Peripheral rim enhancement can be appreciated after gadolinium contrast. The proper clinical context should be applied, as similar characteristics can be seen with other sellar lesions, such as craniopharyngiomas and Rathke's cleft cysts. ${ }^{1-8}$ Assessing the apparent diffusion coefficient on imaging might be helpful, as abscesses will have a reduction in the apparent diffusion coefficient, whereas necrotic tumours will have higher values. $^{9}$

The mainstay of therapy is trans-sphenoidal surgical excision, followed by antibiotic therapy for 4-6 weeks. Empiric therapy consists of ceftriaxone and metronidazole infusions with vancomycin if concerns for Staphylococcus aureus are present prior to culture data guiding therapy. ${ }^{2-6}$ In our case, the patient was initially started on ceftriaxone and vancomycin before transitioning to daptomycin and ertapenem after consultation with infectious disease.

Due to improvements in therapy for pituitary abscesses, mortality has declined from $45 \%$ to $10 \% .{ }^{57}$ At follow-up, $>90 \%$ of patients report improvement in headaches, with $75 \%$ having improvement in visual symptoms versus $16 \%$ without change. Pituitary hormone recovery depends on whether the abscess occurred de novo or in a patient with secondary features, such as an underlying abscess, and when the deficiency began in association with when they developed the abscess. In new hormone deficiencies occurring with the abscess, $25 \%$ of patients had improvement in the deficiency and $63 \%$ had no change. Whereas, in patients where the deficiency had been present prior to developing the abscess, none of those patients had recovery of their hormone deficiency. ${ }^{4-8}$ In our patient, following surgery and antibiotic therapy, her new onset secondary adrenal insufficiency, which presumably started within the last 6 months coinciding with worsening of her chronic headaches and new weight loss, resolved. However, her pre-existing secondary hypothyroidism and amenorrhea diagnosed 3 years prior to presentation persisted.

Fortunately, recurrence rate for patients is low at $\sim 13 \%$, occurring more often in immunocompromised patients. ${ }^{3}$

\section{OUTCOME AND FOLLOW-UP}

Pituitary abscesses are a rare infection. This case highlights the importance of recognising a pituitary abscess even in a patient without meningeal signs. The patient is doing well at her 6-month and 12-month follow-up visits without new headaches or other symptoms.

\section{DISCUSSION}

Pituitary abscesses are a rare infectious process in the sella. It is difficult to diagnose preoperatively due to its non-specific symptoms compared with other pituitary lesions. However, careful history particularly focusing on patient's surgical history and symptoms of diabetes insipidus can help narrow diagnosis. Additionally, contrary to popular belief the most common symptoms are headache, pituitary hormone deficiency and
Table 2 Summary of pituitary abscess management

\begin{tabular}{|c|c|}
\hline \multicolumn{2}{|c|}{ Pituitary abscess management } \\
\hline Signs/symptoms & $\begin{array}{l}\text { More common: headache, anterior pituitary dysfunction, visual field } \\
\text { deficit, diabetes insipidus } \\
\text { Less common: fever, meningismus }\end{array}$ \\
\hline $\begin{array}{l}\text { Imaging } \\
\text { findings }\end{array}$ & $\begin{array}{l}\text { High intensity on T2-weighted images, peripheral enhancement } \\
\text { with gadolinium contrast }\end{array}$ \\
\hline $\begin{array}{l}\text { Common } \\
\text { organisms }\end{array}$ & $\begin{array}{l}\text { Common: gram-positive cocci (Staph and Strep species) } \\
\text { Less common: gram-negative rods, fungal organisms }\end{array}$ \\
\hline Treatment & $\begin{array}{l}\text { Surgical: trans-sphenoidal surgery for drainage } \\
\text { Pharmacologic: empiric ceftriaxone (alternatives: cefotaxime or } \\
\text { cefepime) with metronidazole } \\
\text { Vancomycin if concern for Staphylococcus aureus }\end{array}$ \\
\hline Prognosis & $\begin{array}{l}\text { Mortality: } 10 \% \text { with therapy } \\
\text { Recurrence: }<13 \% \\
\text { Hormone recovery: } 25 \%\end{array}$ \\
\hline Follow-up & $\begin{array}{l}\text { MRI of pituitary, visual field examination and biochemical } \\
\text { evaluation } 3,6 \text { and } 12 \text { months post surgery }\end{array}$ \\
\hline
\end{tabular}

Adopted from references $1-4$.

visual disturbances with fever and meningismus rarely occurring. Management with surgical excision and antibiotics are the mainstays of therapy with a good recovery rate of constitutional symptoms, such as headache and visual disturbances but rare recovery rates of the hormone deficiencies. A summary of this information can be found in table 2 .

\section{Learning points}

Headache, anterior pituitary insufficiency and visual field deficits are the most common presenting symptoms of pituitary abscess.

- Treatment consistent of surgical drainage of abscess, followed by antibiotics.

- Normalisation of recent-onset pituitary hormone insufficiency may occur after surgery, but not long-standing ones.

Twitter Thanh Duc Hoang @tdhdthanh

Acknowledgements None.

Contributors ZWB - author. TSK — reviewer and editor. ZSR—pathology resident reviewed and provided histopathology pictures. TDH—reviewer, editor and mentor.

Funding The authors have not declared a specific grant for this research from any funding agency in the public, commercial or not-for-profit sectors.

Competing interests None declared.

Patient consent for publication Consent obtained directly from patient(s)

Ethics approval The manuscript has been approved by the ethical and IRB.

Provenance and peer review Not commissioned; externally peer reviewed.

Open access This is an open access article distributed in accordance with the Creative Commons Attribution Non Commercial (CC BY-NC 4.0) license, which permits others to distribute, remix, adapt, build upon this work non-commercially, and license their derivative works on different terms, provided the original work is properly cited and the use is non-commercial. See: http://creativecommons.org/ licenses/by-nc/4.0/.

Case reports provide a valuable learning resource for the scientific community and can indicate areas of interest for future research. They should not be used in isolation to guide treatment choices or public health policy.

\section{ORCID iD}

Thanh Duc Hoang http://orcid.org/0000-0001-7437-5604

\section{REFERENCES}

1 Liu Y, Liu F, Liang Q, et al. Pituitary abscess: report of two cases and review of the literature. Neuropsychiatr Dis Treat 2017;13:1521-6. 
2 Cabuk B, Caklılı M, Anık I, et al. Primary pituitary abscess case series and a review of the literature. Neuro Endocrinol Lett 2019:40:99-104.

3 Liu F, Li G, Yao Y, et al. Diagnosis and management of pituitary abscess: experiences from 33 cases. Clin Endocrinol 2011:74:79-88.

4 Vates GE, Berger MS, Wilson CB. Diagnosis and management of pituitary abscess: a review of twenty-four cases. J Neurosurg 2001;95:233-41.

5 Karagiannis AKA, Dimitropoulou F, Papatheodorou A, et al. Pituitary abscess: a case report and review of the literature. Endocrinol Diabetes Metab Case Rep 2016:2016:160014.
6 Gao L, Guo X, Tian R, et al. Pituitary abscess: clinical manifestations, diagnosis and treatment of 66 cases from a large pituitary center over 23 years. Pituitary 2017;20:189-94.

7 Warmbier J, Lüdecke DK, Flitsch J, et al. Typing of inflammatory lesions of the pituitary. Pituitary 2021. doi:10.1007/s11102-021-01180-1. [Epub ahead of print: 31 Aug 2021].

8 Aranda F, García R, Guarda FJ, et al. Rathke's cleft cyst infections and pituitary abscesses: case series and review of the literature. Pituitary 2021:24:374-83.

9 Takayasu T, Yamasaki F, Tominaga A, et al. A pituitary abscess showing high signal intensity on diffusion-weighted imaging. Neurosurg Rev 2006;29:246-8.

Copyright 2021 BMJ Publishing Group. All rights reserved. For permission to reuse any of this content visit https://www.bmj.com/company/products-services/rights-and-licensing/permissions/

BMJ Case Report Fellows may re-use this article for personal use and teaching without any further permission.

Become a Fellow of BMJ Case Reports today and you can:

- Submit as many cases as you like

- Enjoy fast sympathetic peer review and rapid publication of accepted articles

- Access all the published articles

- Re-use any of the published material for personal use and teaching without further permission

Customer Service

If you have any further queries about your subscription, please contact our customer services team on +44 (0) 2071111105 or via email at support@bmj.com.

Visit casereports.bmj.com for more articles like this and to become a Fellow 